\title{
Pollination of Anthurium (Araceae) by derelomine flower weevils (Coleoptera: Curculionidae)
}

\author{
Nico M. Franz \\ Department of Biology, University of Puerto Rico, Mayagüez, PR 00681, Puerto Rico. Fax: (787) 834-3673; \\ franz@uprm.edu
}

Received 01-IX-2003. C Corrected 03-III-2006. Accepted 13-X-2006.

\begin{abstract}
Cyclanthura flower weevils (Coleoptera: Curculionidae: Derelomini) are identified for the first time as pollinators of multiple species of Anthurium (Araceae) in Costa Rica. The weevils are present on the inflorescences in small numbers during the pistillate and staminate phase of anthesis, and consume plant tissues and pollen. The individuals of one species of Cyclanthura can visit several Anthurium species within the same locality. They also engage in reproductive activities and are likely to oviposit into the flowers. The mating strategies suggest that sperm precedence selects males that are able to secure their position as the last partner prior to oviposition. Rev. Biol. Trop. 55 (1): 269-277. Epub 2007 March. 31.
\end{abstract}

Key words: Anthurium, Cyclanthura, evolution, mating, pollination.

In her recent review of the reproductive biology of Araceae (Bown 2000), comments on the paucity of reliable identifications of pollinators for many aroid species, and concludes: "[t]here really is no alternative, whether the species in question grows on the roadside, in the middle of a river, or in the rainforest canopy, than to be there recording every event during flowering." The present report offers such information for several species of Anthurium Schott, an exclusively Neotropical genus with over 800 species (Mayo et al. 1997). Anthurium is morphologically and taxonomically complex, and observed patterns in the anthesis of flowers, the presentation of nectar and pollen are considered relevant to the process of pollination (Croat 1980). A variety of pollinators have been recorded for Anthurium, including euglossines (Dressler 1968) and flies (Madison 1979, Grayum 1990). Madison (1979) notes that A. cf. gualeanum Engler is visited by "weevils" (Coleoptera: Curculionidae) in Ecuador, and this observation has been perpetuated in the literature without additional substance.

Recent progress in the taxonomy of derelomine flower weevils (Franz 2003a) has made it possible to identify the pollinators as members of the Neotropical genus Cyclanthura Franz. This paper presents an account of the behavior of adult Cyclanthura individuals on the inflorescences of Anthurium, based on field observations in Costa Rica and specimen label information throughout the range of the association. The available observations will be evaluated from an evolutionary perspective. The principal aims of this report, however, are to call attention to this interesting plant-pollinator interaction and to stimulate additional studies in the field.

All species of Anthurium are perennial, epiphytic or (less commonly) terrestrial herbs that predominate in low to mid elevation Neotropical wet forests. The individual plants have petioled, coriacious, variously ovate leaves and produce peduncled inflorescences, 
consisting of a spathe and a spadix. Typically, the spathe is persistent, lanceolate, and colored. The spadix is uniform, cylindrical, and colored as well. The inflorescences are monoecious, with the perfect ( $Q \bigcirc^{7}$ ) flowers arranged (and opening) in characteristic spirals along the central axis. The flowers are embedded within the spadix, rhomboidal in shape, with four triangular tepals which enclose the elliptical stigma (Fig. 1). The four flattened stamens are located between the stigma and tepals, and emerge sequentially. In the majority of species of Anthurium, the inflorescences are protogynous, producing stigmatic nectar for some time before the pollen is released (the tepals can also produce nectar during the emergence of the stamens). Like all members of the Araceae they are entomophilous (Grayum 1990), and olfactory signals are considered critical for the attraction of insect pollinators. An extensive account of the spatiotemporal variation of nectar and pollen presentation within Anthurium has been presented by Croat (1980).

The herein reported pollinators are members of the pantropical tribe Derelomini (Coleoptera: Curculionidae: Curculioninae) sensu Franz (2006), which includes more than 40 genera and 265 species (Franz and Valente 2005). Most of them appear to be associated with the inflorescences of Arecaceae (Henderson 1986), although recent efforts have resulted in the identification of numerous species pollinating and/or reproducing on the inflorescences of Cyclanthaceae (Anderson and Gómez 1997, Franz 2001, Franz and O'Brien 2001a y b, Franz 2004). One such clade of 15 Neotropical species has been named Cyclanthura, and is characterized by the presence of elytral elevations and impressions (Franz 2003a). Typically, the adult weevils are $1.8-3.5 \mathrm{~mm}$ in length, (dark) reddish-brown in color, with a shallow impression on the frons (i.e. between the eyes), and a narrow, subrectate rostrum (Fig. 2). Ganglionus Franz \& O'Brien and the taxonomically complex Phyllotrox Schoenherr are considered closely related taxa (Franz 2006). Many species of derelomine flower weevils have adults which function as pollinators and

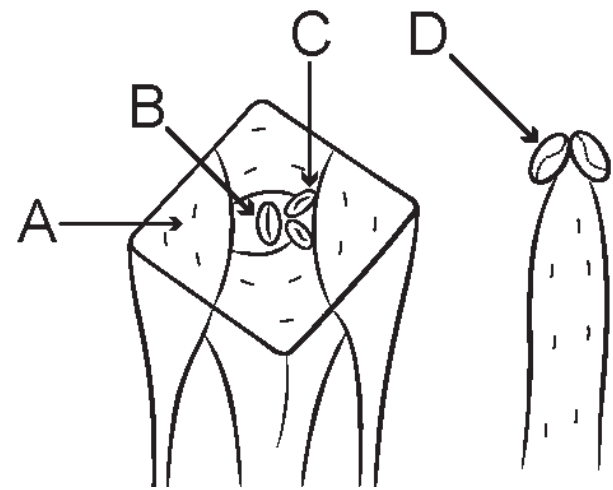

Fig. 1. Representation of an Anthurium flower (adopted from Croat 1980). (A) tepal; (B) pistil (with stigma); (C) anthers; (D) anthers after emergence.

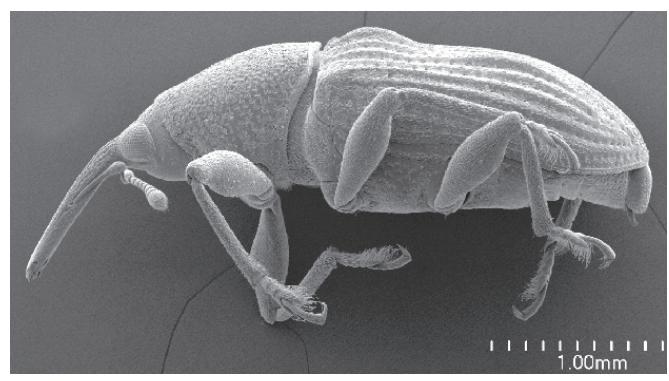

Fig. 2. Habitus of male of Cyclanthura carinata, lateral view.

predominantly detritivorous larvae that do not attack the infructescences or seeds of their host plants. Systenotelus Anderson and Gómez is an exception to this pattern (Anderson and Gómez 1997, Franz 2004, Franz and Valente 2005).

\section{MATERIALS AND METHODS}

Natural history research in Costa Rica focused on Cyclanthura carinata Franz on the inflorescences of Anthurium formosum, A. tilaranense Standley, and $A$. upalaense Croat \& Baker at the Estación Biológica Las Cruces (OET; $08^{\circ} 47^{\prime} \mathrm{N}, 82^{\circ}$ 57' W; elevation 1200 $\mathrm{m}$ above sea level; May 28 to May 31, 2003), and on Cyclanthura laticola Franz on the inflorescences of Anthurium consobrinum at the Estación Biológica La Selva (OET; 10² 26’ N, 
$83^{\circ} 59^{\prime} \mathrm{W}$; elevation $50 \mathrm{~m}$; June 5 to June 8 , 2003). Less extensive observations and collections of Cyclanthura capitulata Franz and C. pilosa Franz on two unidentified species of Anthurium have been conducted in the course of field studies on Cyclanthaceae-associated derelomines at La Selva (Franz 1999; December 1996 to October 1998). An isolated collection of Cyclanthura uncinata Franz on an unidentified Anthurium species has been made at the Reserva Bosque Nuboso Santa Elena (10 $20^{\circ}$ N, $84^{\circ} 48^{\prime}$ W; elevation $1700 \mathrm{~m}$; June 2001).

The adults of Cyclanthura were observed on the flowering inflorescences of Anthurium at various times during the day and night, under low artificial lighting conditions, for periods of 1-5 minutes to 2-3 hours. The weevils were perturbed as little as possible in order to study their natural activities. A total of $95 \min$ of $C$. carinata was filmed at La Cruces, and a total of 50 minutes of $C$. laticola was filmed at La Selva, using a Canon ZR-70MC Mini DV Camcorder in combination with a +4 close-up lens and a flashlight, at distances of 10-20 cm from the inflorescences. All recordings were analyzed frame by frame in the laboratory.

The abundance of weevils was sampled by separating entire inflorescences and transferring them immediately into Whirl-Pak sample bags with $95 \%$ ethanol. Attempts to collect immature stages of Cyclanthura were made by dissecting the infructescences at various stages of the maturation process. Additional information on host plant associations was taken from specimen labels examined during the recent analysis of the genus (Franz 2003a). Relatively little attention was given to the specifics of the anthesis of the various Anthurium species, since this necessitates (inter alia) examination of the stigmata under a microscope over a period of 1-3 weeks (Croat 1980).

\section{RESULTS}

Anthesis of inflorescences: the anthesis of A. formosum (Fig. 3) has a duration of 8-15 days (Beath (1998). It initiates with a pistillate

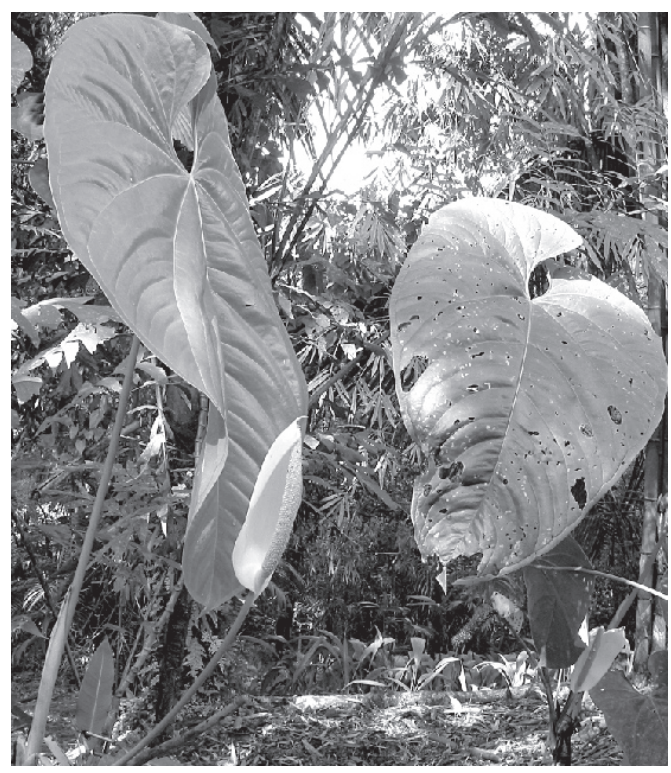

Fig. 3. Habitus of Anthurium formosum at Las Cruces, with flowering spadix and white covering spathe. The incforescences must be approached with extreme caution because any Cyclanthura weevils present tend to let themselves fall to the ground when perturbed and will not return for hours. To an uninitiated observer an inflorescence might well appear unoccupied, although there are 1-3 individuals present near the apex or base of the spadix, where they are covered in part by the spathe.

( + ) phase for 2-3 days, continues for some time with an intermediate (inactive) phase, and ends with a staminate ( $\sigma^{7}$ ) phase for 3-5 days. The opening of the flowers progresses from the base to the apex. The inflorescences produce sweet fragrances from 06:30 a.m. to 10:00 p.m. during each morning of the pistillate and staminate phases. The color of the spathe ranges from white to purple, the spadix is creamy (pale) yellow, and the pistils, anthers and pollen are whitish.

The floral succession of $A$. consobrinum appears to be similar to that of $A$. formosum but was not examined specifically. The spathe is green and the stigmata are situated on conspicuously protruded styles in the course of anthesis.

Pollination: an average of $6.6 \pm 5.6$ individuals of $C$. carinata (range: 2-18 individuals, $\mathrm{N}=8$ ) can be observed on the inflorescences 
of A. formosum at Las Cruces, during all three phases of anthesis. Some inflorescences have no individuals present. The weevils will typically rest in protected areas near the apez or base of the spadix where they are covered in part by the spathe, and move only minimally for minutes to hours. Only one individual of $C$. carinata has been confirmed to arrive in flight on an inflorescence at 9:20 A.M. (i.e. when the fragrances are produced), landing on the inside surface of the spathe and crawling immediately towards the base of the spadix. None have been observed to leave without returning after some time. Once they are there, however, they will likely stay for most of the flowering time. Presumably the same individuals have been identified on various inflorescences for as long as 2-4 days.

The weevils are not exclusive pollen eaters but can also consume parts the pistils and triangular tepals, inserting the rostrum well into the flowers (for over $5 \mathrm{~min}$ on one occasion). Several circular spots of decaying plant tissue are evidence for such activities. Crawling along the spadix, individuals can also probe 5 stigmata in $45 \mathrm{~s}$ or 15 stigmata in $200 \mathrm{~s}$, although these are "exceptions" to the predominant resting. They will eventually access the entire inflorescence surface for feeding and contact the protruded stigmata with the legs, sterna, venter, and rostrum. The open (extruded) anthers are spaced at 2-4 $\mathrm{mm}$ from each other, and therefore individual can only consume pollen with the rostrum while touching other anthers, thereby acquiring pollen. On average the process of feeding on an anther lasts $33 \pm 16$ s (range: $5-70 \mathrm{~s}, \mathrm{~N}=28$ ). In the course of time, macroscopically visible packages of pollen accumulate on the weevils (Fig. 4). The pollen can be transferred when they fly to other inflorescences with receptive stigmata.

Even smaller numbers of $C$. laticola have been collected on $A$. consobrinum at La Selva (average: $2.6 \pm 2.0$ individuals per inflorescence, range: $0-6$ individuals, $\mathrm{N}=10$ ), during both the pistillate and the staminate phase of anthesis. All other observations are congruent with those presented above. Additional information on

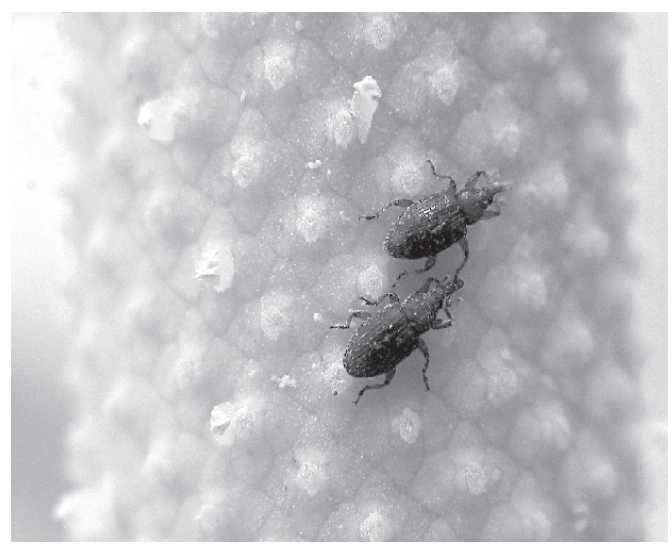

Fig. 4. Individuals of $C$. carinata with packages of pollen on the rostrum, legs, and elytra. Some emerged anthers are visible.

Cyclanthura pollinators of Anthurium species is provided in Table 1 .

Reproduction: the following account is based primarily on video-recorded observations of six individuals (three females, three males) of $C$. carinata on an inflorescence of A. formosum during the staminate phase of anthesis. Over a period of approximately 75 min, a male was associated with a female that appeared to be preparing for oviposition. The female was located in the central region of the spadix on the side facing the spathe. A second female and a second male were consuming pollen in the immediate vicinity (i.e. at a distance of no more than $1-3 \mathrm{~cm}$ ). A third male was resting near the base of the spadix, and a third female was inserting her rostrum into the tepals of a flower situated near the apex and covered by the spathe. These observations are reflective of the general tendencies of the weevils to either (1) engage in feeding or mating in areas of flowering activity or (2) rest in protected regions of the inflorescence.

The mating couple was positioned in such a way the female was stationary and closely "pressed" against the inflorescence surface. The considerably smaller male was situated along her abdomen, at an angle of $45^{\circ}$, with the hind legs on the plant, the mid legs on the elytra of the female, and the fore legs available 
TABLE 1

Overview of recollections of Cyclanthura on the inflorescences of Anthurium in the Neotropics

SPECIES

ASSOCIATION

LOCALITY $^{1}$

QUANTITY

15

$2-18$

4

4

$0-6$

23

5

10

3

?
REREFENCE $^{2}$

PO

LI (L. D. Gómez)

PO

PO

PO

LI (C. W. O’Brien)

PO

LI (D. R. Whitehead)

PO

Madison 1979

$1 \mathrm{CR}=$ Costa Rica, EC=Ecuador, PA=Panama; for specific locality information see Franz (2003a).

$2 \mathrm{LI}=$ label information (with collector named), $\mathrm{PO}=$ personal observation.

for courtship. Every 2-5 min the male used the legs and particularly the rostrum to perform abrupt yet rhythmic pushes on the elytra of the female - approximately two per second - for a period of 5-15 s $(\mathrm{N}=5)$. In the course of the behavioral displays the male aedeagus continued to be inserted into the female for $1 / 3$ to $2 / 3$ of its length. After this activity they rested in the same relative position.

Three attacks to replace the copulating male were launched by the closely associated male. The aggressions were separated by over $25 \mathrm{~min}$ and over $5 \mathrm{~min}$, respectively. For the first of these the attacking male crawled over the female to face his smaller competitor frontally. The challenged male reacted by assuming an (almost) erect position, standing exclusively on the hind legs and holding the fore legs constant at an angle in front of him, apparently to signal the disposition to fight (Fig. 5). After 20 $\mathrm{s}$ of staying in place on the female, the attacking male then descended and attempted to move into the position of the (still) copulating male by aligning next to him and pushing him from the side. The challenged male used his fore legs to hit the attacker on the elytra and pronotum,

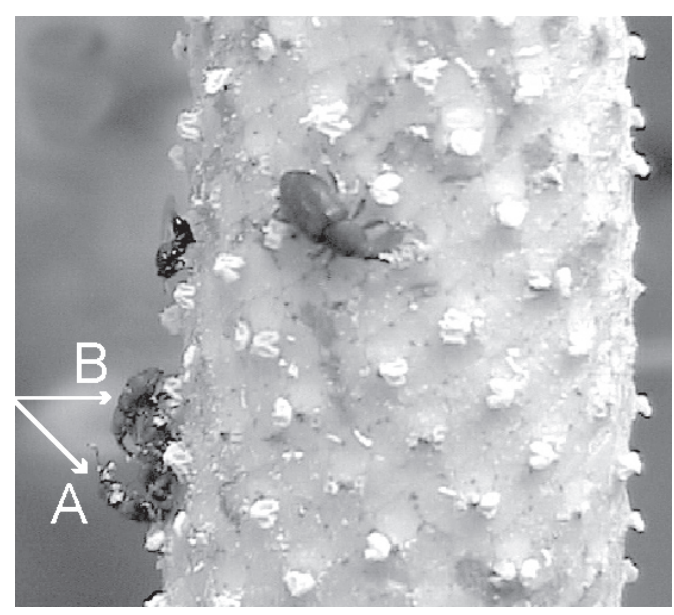

Fig. 5. Mating activities of $C$. carinata on an inflorescence of $A$. formosum during the staminate phase of anthesis. The copulating male (A) assumes an erect position and lifts the fore legs after the attacking male (B) crawls on top of the stationary female. Another (larger) female is present as well. Several spots of decaying tissue indicate previous consumption of tepals by the weevils.

but lost his position for only $10 \mathrm{~s}$ before regaining it by pushing the attacker away frontally. Although the attacking male had never copulated with the (mostly unaffected) female, the 
successful male resumed his copulatory and courting activities immediately. The attacker remained in the vicinity. The entire sequence lasted 1 minute.

At one time the unsuccessful male attempted to mate with another female by positioning his fore legs on her abdomen. She continued to crawl along while consuming pollen and the male eventually moved away. He launched his second attack on the copulating male - this time from the posterior side - by attempting to lift him up with the rostrum. The attacked male, however, was able to secure his position on the female, causing the other to leave after $25 \mathrm{~s}$. He returned very shortly by crawling frontally onto the female. This provoked the copulating male to resume the "fighting position" (Fig. 5), and the attack terminated.

The third attack was launched from the side. This time the attacking male succeeded in lifting the smaller male up with the rostrum and locating himself on top of the (slowly moving) female, after $30 \mathrm{~s}$ of conflict. Once in position he was able to counter one short attack and remained there permanently. The newly associated couple crawled underneath the spathe where any oviposition activities were impossible to track.

Additional studies of $C$. carinata on $A$. formosum, A. tilaranense, and A. upalaense at Las Cruces yielded similar observations. It is common to locate individuals in copula yet also resting on top of each other for longer periods of time. The couples will separate when perturbed. The female can apparently signal an indisposition to mate either (1) by continuing to move while the male attempts to crawl on top of her, or (2) by lifting her entire body for 3-5 s, resting for some time, and then lowering herself (i.e. touching the inflorescence surface with the abdomen). She can perpetuate this activity for (minimally) $30 \mathrm{~s}(\mathrm{~N}=3)$.

A total of 12 infructescences of $A$. formosum were examined at various stages of maturation for immatures (larvae and pupae) of $C$. carinata. Although five of them had signs of infestations by herbivorous insects - i.e. decaying ovarian tissue and constrictions in shape - no living immatures of weevils could be located. Unidentified larvae of insects have been noted occasionally during dissections of Anthurium infructescences (T. B. Croat, pers. comm.).

Observations of C. laticola on A. consobrinum at La Selva evidenced even less activity by the weevils. When in copula the male continuously moved back and forth while contacting the head region of the female with his antennae, legs, and rostrum. Conflicts among males were not observed. Various dissected infructescences yielded no Cyclanthura specimens.

\section{DISCUSSION}

The most critical result of the present study is the confirmation of Cyclanthura weevils as pollinators of multiple species of Anthurium in Costa Rica (and additional Neotropical countries). Previous reports have identified euglossines bees as common visitors of members of this aroid clade (Williams and Dressler 1976). At Las Cruces, Beath (1998) observed males of Euglossa and Eulaema on the inflorescences of A. formosum and A. hacumense Engler, noting that they collect fragrant surface waxes for pheromones used in the attraction of females. Many euglossine species are polylectic, however, and cannot be expected to pollinate Anthurium constantly and/or exclusively (Roubik 1989). Other floral visitors included chrysomelids, nymphs of hemipterans, small parasitoid wasps, and thrips (but not euglossines). None of these are sufficiently behaviorally synchronized with the anthesis of Anthurium to act as reliable pollinators. In contrast to this, many species of derelomine flower weevils are pollinators of such morphologically complex taxa as Arecaceae and Cyclanthaceae (Henderson 1986, Eriksson 1994, Franz 2004). This pollinating function appears to be plesiomorphic for the clade that comprises Cyclanthura, Ganglionus, and Phyllotrox. It is present in other Cyclanthura species as well, e.g. in $C$. bipartita Franz which pollinates Cyclanthus bipartitus Poiteau in southwestern Costa Rica (Franz 2003a). What characterizes the weevils 
is the specific (olfactory) attraction to their host plants, the disposition to stay for the period of anthesis while consuming and reproducing on the floral organs, and the ability to transfer considerable amounts of pollen when leaving for other receptive inflorescences. Their morphologies and behaviors facilitate this process. Individuals of Cyclanthura have been collected either on Anthurium or on Cyclanthaceae (although never on both), and nowhere else. In spite of their low abundance and generally low activity, they should be considered the most effective pollinators of the species listed above (Table 1).

The weevils are typically not associated with their host plants at the level of species. They visit similar Anthurium species when they occur in the same locality. There appears to be little phylogenetic signal in the patterns of association. As an example, A. formosum, A. tilaranense, and $A$. upalaense are all visited by C. carinata at Las Cruces yet have been placed in separate taxonomic sections (see Croat and Sheffer 1983). The same situation obtains for the evolutionarily largely unrelated. $A$. consobrinum and A. ochranthum Koch which attract weevils of $C$. laticola. The reproductive cohesion of these Anthurium species must be achieved by mechanisms complementing those provided by their pollinating agents.

With respect to the phylogeny of Cyclanthura, the species in Table 1 are part of a monophyletic clade that includes $C$. cordata Franz from Ecuador - where Madison (1979) observed weevils on Anthurium and C. dentata Franz from Panama with unknown host associations. Based on this information, derelomines have colonized the inflorescences of Anthurium at only one time in past.

Considering the number of potential host taxa involved and the paucity of field studies in the Neotropics (Grayum 1990, Mayo et al. 1997, Bown 2000), future research will likely identify many additional species of Cyclanthura as pollinators of this aroid complex. Interestingly, C. sphaerata Franz is the only species within the clade mentioned above that does not visit Anthurium. Instead, the weevils are (presumably secondarily) associated with Sphaeradenia Harling (Cyclanthaceae), e.g. in Monteverde, Costa Rica. The immature stages of C. sphaerata consume the pulp of the maturing infructescences. This might be indicative of the biology of other Cyclanthura species.

The mating activities of $C$. carinata and $C$. laticola suggest that they oviposit into the inflorescences of Anthurium. The females of many derelomine species will only copulate with males if they are close to initiating oviposition. As an example, the females of Staminodeus vectoris Franz visit significantly more Cyclanthaceae species at La Selva than they mate on and oviposit into (Franz 2003b). On the "non-ovipositing" inflorescences they will not accept males attempting to copulate. Conversely, if sperm precedence is assumed then it would be advantageous for males to invest into copulation, courtship, and conflicts with competitors (as reported above) so long as they can assess whether the females will lay eggs. Similar mating conditions have been observed in other weevil species where individuals aggregate in numbers on ephemeral substrates for oviposition (Eberhard 1983).

In light of the long flowering periods and small numbers of individuals present, competition among males is common on the inflorescences of Anthurium. They can apparently assess whether females are ready to reproduce but are unable to predict the exact timing of oviposition. Thus the general male strategy is to associate with one active female until she lays an egg. This is most convincingly explained if one assumes sperm precedence (Simmons 2001): a male prefers to secure himself as the last partner of a female prior to oviposition over mating at any time with many females. Relevant to this context is the observation that the courtship of males is not very elaborate and males are able to maintain their copulatory position when attacked by slightly larger competitors. Similar mating conditions occur in derelomines associated with Cyclanthaceae (Franz 1999).

While the present report of Cyclanthura weevils on Anthurium inflorescences is based 
on limited observations, it is hoped that it will stimulate more studies in the field that address not only the pollination ecology of this interaction but also potential behavioral homologies within derelomine flower weevils.

\section{ACKNOWLEDGMENTS}

I thank Thomas Croat, Luis Gómez, Alvaro Herrera, Robert Matlock for access to field sites and assistance with plant identifications; Robert Anderson, Steven Lingafelter, and Charles O'Brien for loans of weevil specimens; and Huyen Do for assistance with the filming and photography and for general support throughout the project. David Grimaldi and Tam Nguyen facilitated the use of the SEM at the American Museum of Natural History. Funding was provided in part through the National Science Foundation Doctoral Dissertation Improvement Grant DEB-0206093.

\section{RESUMEN}

Por primera vez se informa que algunos curculiónidos de flores de Cyclanthura (Coleoptera: Curculionidae: Derelomini) polinizan varias especies de Anthurium (Araceae) en Costa Rica. Los curculiónidos están presentes en las inflorescencias en pequeñas cantidades durante la fase pistilada y estaminada de la antesis, y consumen tejidos de la planta y polen. Los individuos de una especie de Cyclanthura pueden visitar varias especies de Anthurium en la misma localidad ; también se ocupan en actividades reproductivas y probablemente ovipositan en las flores. Las estrategias de apareamiento sugieren que la competencia a nivel de gametos selecciona favorablemente al último macho en la secuencia de apareamiento de la hembra, pues éste deposita su semen justo antes de que ella oviposite.

Palabres clave: Anthurium, Cyclanthura, evolución, apareamiento, polinización.

\section{REFERENCES}

Anderson, R.S. \& L.D. Gómez-P. 1997. Systenotelus, a remarkable new genus of weevil (Coleoptera: Curculionidae) associated with Carludovica
(Cyclanthaceae) in Costa Rica and Panamá. Rev. Biol. Trop. 45: 887-904.

Bown, D. 2000. Aroids: plants of the arum family, second edition. Timber, Portland, Oregon, USA. 468 p.

Croat, T.B. 1980. Flowering behavior of the Neotropical genus Anthurium (Araceae). Amer. J. Bot. 67: 888904.

Croat, T.B. \& R.S. Sheffer. 1983. The sectional groupings of Anthurium (Araceae). Aroideana 6: 85-123.

Dressler, R.L. 1968. Observations on orchids and euglossine bees in Panama and Costa Rica. Rev. Biol. Trop. 15: $143-183$.

Eberhard, W.G. 1983. Behavior of adult bottle brush weevils (Rhinostomus barbirostris) (Coleoptera: Curculionidae). Rev. Biol. Trop. 31: 233-244.

Eriksson, R. 1994. The remarkable weevil pollination of the Neotropical Carludovicoideae (Cyclanthaceae). Plant Syst. Evol. 189: 75-81.

Franz, N.M. 1999. Biología reproductiva de algunas ciclantáceas (Cyclanthaceae) y de los picudos asociados (Coleoptera: Curculionidae). Tesis de Maestría, Universidad de Costa Rica, San José, Costa Rica. 97 p.

Franz, N.M. 2001. Description and phylogeny of Staminodeus, a new genus of Derelomini (Coleoptera: Curculionidae) associated with Cyclanthaceae. Coleop. Bull. 55: 397-418.

Franz, N.M. 2003a. Systematics of Cyclanthura, a new genus of Derelomini (Coleoptera: Curculionidae). Insect Syst. Evol. 34: 153-198.

Franz, N.M. 2003b. Mating behaviour of Staminodeus vectoris (Coleoptera: Curculionidae), and the value of systematics in behavioural studies. J. Nat. Hist. 37: $1727-1750$.

Franz, N.M. 2004. Analyzing the history of the derelomine flower weevil-Carludovica association (Coleoptera: Curculionidae; Cyclanthaceae). Biol. J. Linn. Soc. 81: 483-517.

Franz, N.M. 2006. Towards a phylogenetic system of derelomine flower weevils (Coleoptera: Curculionidae). Syst. Ent. 31. (in press).

Franz, N.M. \& C.W. O’Brien. 2001a. Ganglionus, a new genus of Derelomini (Coleoptera: Curculionidae) associated with Carludovica (Cyclanthaceae). Ann. Entomol. Soc. Am. 74: 835-850.

Franz, N.M. \& C.W. O’Brien. 2001b. Revision and phylogeny of Perelleschus (Coleoptera: Curculionidae), 
with notes on its association with Carludovica (Cyclanthaceae). Trans. Am. Entomol. Soc. 127: 255-287.

Franz, N.M. \& R.M. Valente. 2005. Evolutionary trends in derelomine flower weevils: from associations to homology. Invert. Syst. 19: 499-530.

Grayum, M.H. 1990. Evolution and phylogeny of the Araceae. Ann. Missouri Bot. Gard. 77: 628-697.

Henderson, A. 1986. A review of pollination studies in the Palmae. Bot. Rev. 52: 221-259.

Madison, M. 1979. Protection of developing seeds in Neotropical Araceae. Aroideana 2: 52-61.

Mayo, S.J., J.Bogner \& P.C. Boyce. 1997. The genera of Araceae, with contributions from J.C. French and R. Hegnauer, illustrations by E. Catherine. Royal Botanical Gardens, Kew. 370 p.
Roubik, D.W. 1989. Ecology and natural history of tropical bees. Cambridge University, Cambridge, New York, USA. 514 p.

Simmons, L.W. 2001. Sperm competition and its evolutionary consequences in the insects. Princeton University, Princeton, New Jersey, USA. 434 p.

Williams, N.H. \& R.L. Dressler. 1976. Euglossine pollination of Spathiphyllum (Araceae). Selbyana 1: 349-356.

\section{INTERNET REFERENCE}

Beath, D.D.N. 1998. Pollination ecology of the Araceae. U.S.A. (Downloaded: 01-3-2006; http://www.aroid. org/pollination/beath/index.html) 
